\title{
The effect of sulfated zirconia and zirconium phosphate nano- composite membranes on fuel cell efficiency
}

\author{
Rudzani Sigwadii ${ }^{*}$; Touhami Mokranii ${ }^{1}$ PF Msomi2 ${ }^{2}$ Fulufhelo Nemavhola ${ }^{3}$ \\ 1 Department of Chemical Engineering, School of Engineering, University of South Africa, Private Bag X6, \\ Florida, 1710, South Africa ; Sigwara@unisa.ac.za \\ 2 Department of Applied Chemistry, University of Johannesburg, Johannesburg, South Africa; \\ pmsomi@uj.ac.za \\ 3 Department of Mechanical Engineering, School of Engineering, University of South Africa, Private Bag X6, \\ Florida, 1710, South Africa; masitfj@unisa.ac.za \\ * Correspondence: Sigwara@unisa.ac.za ; Tel.: +2711 4712354
}

\begin{abstract}
To investigate the effect of acidic nanoparticles on proton conductivity, permeability and fuel cell performance, a commercial Nafion ${ }^{\otimes} 117$ membrane was impregnated with zirconium phosphates $(\mathrm{ZrP})$ and sulfated zirconium $\left(\mathrm{S}-\mathrm{ZrO}_{2}\right)$ nanoparticles. The tensile test, water uptake, methanol crossover, Fourier-transform infrared spectroscopy (FTIR), X-ray diffraction (XRD), Thermal gravimetric analysis (TGA) and Scanning Electron Microscopy (SEM) were used to assess the capacity of nanocomposite membrane to function in a fuel cell. The modified Nafion ${ }^{\circledR}$ membrane obtained the higher water uptake and a lower water content angle than the commercial Nafion ${ }^{\circledR} 117$ membrane, indicating that it has a greater impact on conductivity. Under strain rates of 40,30 and $20 \mathrm{~mm} / \mathrm{min}$, the nanocomposite membranes demonstrate more stable thermal deterioration and higher mechanical strength, which offers tremendous promise for fuel cell applications. When compared to 0.113 $\mathrm{S} / \mathrm{cm}$ and $0.013 \mathrm{~S} / \mathrm{cm}$, respectively, of commercial Nafion ${ }^{\circledast} 117$ and $\mathrm{Nafion}^{\otimes} \mathrm{ZrP}$ membranes, the modified Nafion ${ }^{\circledR}$ membrane with ammonia sulphate acid had the highest proton conductivity of $7.891 \mathrm{~S} / \mathrm{cm}$. When tested using a direct single cell methanol fuel cell, it had the highest power density of $183 \mathrm{~m} . \mathrm{cm}^{-2}$ which is better than commercial Nafion ${ }^{\circledR} 117$ and Nafion ${ }^{\circledast} \mathrm{ZrP}$ membranes.
\end{abstract}

Keywords: Sulphated zirconium oxide; zirconium phosphates; incorporation; water contact angle, fuel cell efficiency.

\section{Introduction}

Because of their outstanding conversion efficiency, high power density, and zero pollution emissions, proton exchange membrane fuel cells (PEMFCs) are regarded environmentally acceptable energy conversion devices for both stationary and portable power applications [1]. Proton exchange membranes (PEMs) are a key component of PEMFCs because they carry protons between the anode and the cathode while isolating electrons and avoiding fuel crossover. Electrochemical devices that are both durable and efficient, such as PEMFCs and beyond Li-ion batteries like Li-sulfur [2,3] and $\mathrm{Li}^{-\mathrm{O}_{2}}$, [4-6]. PEMs such as Nafion ${ }^{\circledR 117}$ maintains a greater conductivity, mechanical and chemical stability at lower temperatures in fuel cells [7-11]. Its phase of separation between the Nafion ${ }^{\oplus ' s}$ two major monomers which are the hydrophobic Teflon-like backbone and the hydrophilic sulfonic-acid-terminated side chain, determines its characteristics. The thermo-chemical environment and material interfaces of Nafion ${ }^{\circledR}$ play a big role in this segregation. However, when run at higher temperatures, these perfluorosulfonic acid membranes face issues such as increased fuel crossover and reduced proton conductivity due to water loss, as well as a higher cost, limiting their use in PEMFCs $[12,13]$. The insertion of nanosized 
inorganic fillers into the polymeric matrix to construct hybrid composite membranes has received a lot of study interest among all the ways that have been investigated to synthesise efficient PEMs materials [14]. At low to medium temperatures, the introduction of hygroscopic inorganic nanomaterials such as silica, titanium dioxide, zirconium dioxide, nanoclays and others into the polymer matrix has improved features of composite membranes such as water retention capacity and ionic conductivity [15]. These hydrophilic fillers can provide a lot of hydrogen bonding sites, allowing membranes to absorb a lot of water. When the amount of filler is increased, it weaken the link between the organic polymer and inorganic filler which causes poor interfacial interaction, resulting in a loss of conductivity [6].

When inorganic acid such as sulfated zirconia calcined at $300^{\circ} \mathrm{C}$, it improves proton conductivity $(14.5 \mathrm{mS} / \mathrm{cm})$, with better ion exchange capacities (IEC) of $0.54 \mathrm{meq} / \mathrm{g}$ and greater water uptake due to sulfate ions, which raises the sulfonic acid content inside the membrane [16]. Furthermore, the addition of sulfated zirconia to the membrane gives an additional proton ion within the Nafion matrix. In addition, the modified Nafion ${ }^{\circledR}$ membrane containing S- $\mathrm{ZrO}_{2}$ nanoparticles exhibits less swelling, better mechanical properties, and lower methanol permeability. Although mesoporous sulfated zirconia offers the potential to broaden the applications of zirconia-based acid materials, its low thermal stability remains a major drawback, causing the mesoporous to collapse when the template is removed at a high temperature. Zirconia is predominantly cationic rather than polyxo in high acidic conditions. However, the polyoxo ions can occur when zirconia is sulfated with ammonia sulfate $\left[\mathrm{Zr}(\mathrm{OH})_{2}\left(\mathrm{SO}_{4}{ }^{2-}\right) \times\left(\mathrm{H}_{2} \mathrm{O}\right)\right] \mathrm{n}^{\mathrm{n}(2-2 x)}$ [17]. At temperatures above $100{ }^{\circ} \mathrm{C}$, the hydroxyl groups on the oxide surface can effectively retain water molecules and prevent membrane dehydration. Furthermore, incorporating $\mathrm{S}-\mathrm{ZrO}_{2}$ nanoparticles into Nafion ${ }^{\circledR}$ membranes enhances the sensitivity to high-temperature response. Zirconia oxide is the sole metal oxide with four chemical properties: acidity, basicity, reducing or oxidizing agents [18].

The fascinating a zirconium phosphate $(\mathrm{ZrP})$, a layered acidic inorganic cation exchange material with the formula $\mathrm{Zr}\left(\mathrm{HPO}_{4}\right)_{2} 2 \mathrm{H}_{2} \mathrm{O}$, has been extensively explored [19]. $\mathrm{ZrP}$ is known for its great thermal and chemical stability, as well as its high ion conductivity and mechanical strength. Its layered construction enables for the incorporation of numerous guest species of diverse sizes between their layers [20, 21]. ZrP has been integrated into several polymer-based nanocomposites in recent investigations, which showed good mechanical, thermal, and barrier properties [22]. The major goal of this article is to use sulfated and phosphated zirconia nanoparticles to modify Nafion ${ }^{\circledR}$ membranes to achieve high proton conductivity, good thermal and chemical stability, and improved water absorption.

\section{Materials and Methods}

\subsection{Materials}

Phosphoric acid (Sigma), ammonium sulphate (Sigma), zirconium oxychloride hydrate (Merck), sulfuric acid (Merck), Nafion ${ }^{\circledR} 117$ membrane (Sigma), methanol (Sigma), and hydrogen peroxide (Merck) were used exactly as they were supplied.

\subsection{Membrane nanocomposite synthesis}

To eliminate contaminants, Nafion ${ }^{\circledR} 117$ membranes were boiled for 1 hour in hydrogen peroxide ( 3 percent solution), then boiled in sulfuric acid $(0.5 \mathrm{M})$, and finally boiled in distilled water [23]. After pre-soaking the pure membranes in methanol to open the pores, $5 \mathrm{wt} \%$ of $\mathrm{ZrP}$ [9]. and $\mathrm{S}-\mathrm{ZrO}_{2}$ [24] nanoparticles were added. The membrane was soaked five times before being heated at $100{ }^{\circ} \mathrm{C}$ for 2 hours [25]. The obtained solution was maintained at room temperature for 24 hours. The thicknesses of the membranes were measured using a digital micrometer $(0.18 \mathrm{~mm})$. To record the accurate number, the thickness reading was recorded more than thrice. 


\subsection{Characterisations}

Fourier-transform infrared spectroscopy (FTIR), scanning electron microscopy (SEM), X-ray diffraction (XRD) examination, and thermal gravimetric analysis (TGA) were used to characterize the membranes.

\subsection{Tensile test}

Under a uniaxial testing system, the mechanical strength of membranes was measured. The breadth, thickness, and length were all measured using a Vernier calliper. All membranes had a clamping area of $4 \mathrm{~mm} \times 10 \mathrm{~mm}$. The tension applied to the sample was calculated using the observed thickness of $0.18 \mathrm{~mm}$. Membranes were measured at $25{ }^{\circ} \mathrm{C}$ using the CellScale Ustretch instrument with actuator speeds of 40,30 and 20 $\mathrm{mm} / \mathrm{min}$.

\subsection{Measurements of the water contact angle}

Contact angles were used to determine the hydrophilicity of the membrane surfaces (Phoenix 300 contact angle analyser instrument equipped with a video system). For analysis, membrane was cut into strips and put on glass slides. By putting the tip of the syringe close to the sample surface, a droplet of deionized water $(0.16 \mathrm{~L})$ was placed onto the surface of membranes at ambient temperature. To get an average value, the measurement was performed ten times at various membrane surfaces. The wetting process was recorded prior to the water droplet adhering to the sample's surface until there was no more noticeable change at the surface.

\subsection{Water uptake ((WU)) and swelling ratio (SR)}

The membranes were immersed in distilled water for $24 \mathrm{hrs}$ at different temperatures of $80^{\circ} \mathrm{C}, 60^{\circ} \mathrm{C}$, and $30^{\circ} \mathrm{C}$ and then weighed and measured. Using the equations below, the water uptake and swelling ratio of soaked membrane were calculated:

$$
\begin{aligned}
& \mathbf{W}_{\mathrm{up}}=\frac{\left(\mathbf{m}_{\mathrm{wet}}-\mathbf{m}_{\mathrm{dry}}\right)}{\mathbf{m}_{\mathrm{dry}}} \times \mathbf{1 0 0} \% \\
& \mathbf{S R}=\frac{\left(\mathbf{L}_{\mathbf{w}}-\mathbf{L}_{\mathrm{d}}\right)}{\mathbf{L}_{\mathrm{d}}} \mathbf{x} \mathbf{1 0 0} \%
\end{aligned}
$$

Where $\mathrm{W}_{\text {up }}$ is the $\mathrm{WU}$ percentage, $\mathrm{m}_{\text {wet, }}$ membrane wet mass and $\mathrm{m}_{\text {dry }}$, membrane dry mass, $L_{w}$ membrane wet length and $L_{d}$ dried length of membrane.

\subsection{Ion exchange capacity (IEC)}

The IEC of membranes was determined using the equation below based on the titrated results:

$$
\text { IEC }=\frac{\mathrm{v}_{\mathrm{NaOH}} \times \mathrm{C}_{\mathrm{NaOH}}}{\mathrm{m}_{\mathrm{d}}}
$$

The volume of titrated $\mathrm{NaOH}$ is $\mathrm{VNaOH}$ and the membrane dried mass is md.

\subsection{Measurements of the methanol permeability}

A two-compartment permeation-measuring cell was used to determine the methanol crossover. Methanol solution $(50 \mathrm{~mL})$ in compartment $(\mathrm{A})$ and distilled water in compartment (B) $(50 \mathrm{~mL})$. With a diffusion area diameter of $3.5 \mathrm{~cm}$, the membrane was installed between the two compartments. The readings were collected at $30^{\circ} \mathrm{C}, 60^{\circ} \mathrm{C}$, and $80^{\circ} \mathrm{C}$ using $5 \mathrm{M}$ and $2 \mathrm{M}$ methanol solutions. The following equation was used to compute methanol permeability $(\mathrm{P})$ :

$$
C_{B}=\frac{A P}{V_{B} L} C_{A}\left(t-t_{o}\right)
$$


where $C_{B}(t)$ is the methanol concentration in compartment $B$ at time $t$; Methanol content in compartment $A$ is denoted by $C_{A}$, in compartment $B, V_{B}$ represents the volume of distilled water, the effective permeating area is $\mathrm{A}$, and the membrane thickness is $\mathrm{L}$.

\subsection{Measurement of the proton conductivity}

A four-point probe conductivity cell was used to measure the conductivities of the membranes. At $0.1 \mathrm{~mA}$ current and $1 \mathrm{MHz}$ to $10 \mathrm{~Hz}$ frequency, the proton conductivity was measured galvanostatically and estimated using the equation below:

$$
\sigma=\frac{L}{A R_{S}}
$$

where Rs denotes the measured membrane resistance, the area of the membrane normal to the current flow is $\mathrm{A}$, and the thickness of the membrane is $\mathrm{L}$.

\subsection{The Cell Polarization and the Fabrication of Membrane Electrode Assembly}

The performance of the membranes was tested using a direct methanol fuel cell (DMFC). Pt on carbon cloth was used for the anode and cathode membrane electrode assemblies (MEA). Without the use of hot pressing, the MEA was put together. At $60{ }^{\circ} \mathrm{C}$, fuel cells were tested with a $2 \mathrm{M}$ methanol solution. On a single fuel cell test, the galvanostatic potential of the fuel cell was measured in the open air.

\section{Results}

This section may be divided by subheadings. It should provide a concise and precise description

3.1 Fourier Transform Infrared

In comparison to Nafion ${ }^{\circledR} 117$ membrane, Figure 1 illustrates the FTIR spectra of Nafion ${ }^{\circledR} \mathrm{S}-\mathrm{ZrO}_{2}$ and Nafion ${ }^{\circledR} \mathrm{ZrP}$ nanocomposite membranes. The O-H stretching vibration of the membranes is $3456 \mathrm{~cm}^{-1}$, which corresponds to physically adsorbed water [26, 27] and Figure 1(a-c) shows the O-H bending vibration of free water molecules at 1630 $\mathrm{cm}^{-1}$. However, as shown in Figure 1(a-c), the peaks at $3456 \mathrm{~cm}^{-1}$ for nanocomposite membranes are shallower than those for commercial membranes. This could be because nanoparticles are incorporated into the nanocomposite membranes, which increases the water content. Additionally, due to symmetric S-O stretching, the membranes have a comparable peak at $1060 \mathrm{~cm}^{-1}[28,29]$ and a band at $1145 \mathrm{~cm}^{-1}$ and $1201 \mathrm{~cm}^{-1}$ were formed due to symmetric C-F stretching [30]. Furthermore, the C-O-C stretching caused the peaks at $976 \mathrm{~cm}^{-1}[30]$ (Di Noto et al., 2006)(Di Noto et al., 2006)(Di Noto et al., 2006)(Di Noto et al., 2006)(Di Noto et al., 2006)(Di Noto et al., 2006) and the $512 \mathrm{~cm}^{-1}$ band is due to symmetric O-S-O bending, whereas the $632 \mathrm{~cm}^{-1}$ band is due to C-S group stretching [30, 31]. Asymmetric stretching vibrations of the $\mathrm{Zr}-\mathrm{O}-\mathrm{Zr}$ bond were also assigned to the peaks at 636 $\mathrm{cm}^{-1}$ and $515 \mathrm{~cm}^{-1}$, respectively, which are identical to the Nafion ${ }^{\circledR} 117$ membrane's transmittance peaks [32]. This could be owing to the Nafion ${ }^{\circledR}$ matrix's well-distributed inorganic components. The bands at $1619 \mathrm{~cm}^{-1}$ were allocated to $\mathrm{H}-\mathrm{O}-\mathrm{H}$ bending vibration mode in Figure 1(a), this may be owing to the sulfate group's coordinated molecular water [32]. The peaks of $\mathrm{Zr}-\mathrm{O}$ and $\mathrm{P}-\mathrm{O}_{4}$ can be seen in Figure 1(b) at $797 \mathrm{~cm}^{-1}, 509 \mathrm{~cm}^{-1}$, and $446 \mathrm{~cm}^{-1}$, respectively, this could be due to $\mathrm{ZrP}$ nanoparticles embedded in the Nafion ${ }^{\circledR}$ membrane and the $\mathrm{C}-\mathrm{H}$ stretching of the modified Nafion ${ }^{\circledR}$ membrane, with stretch vibrations between $2925 \mathrm{~cm}^{-1}$ and $2852 \mathrm{~cm}^{-1}[33,34]$. 


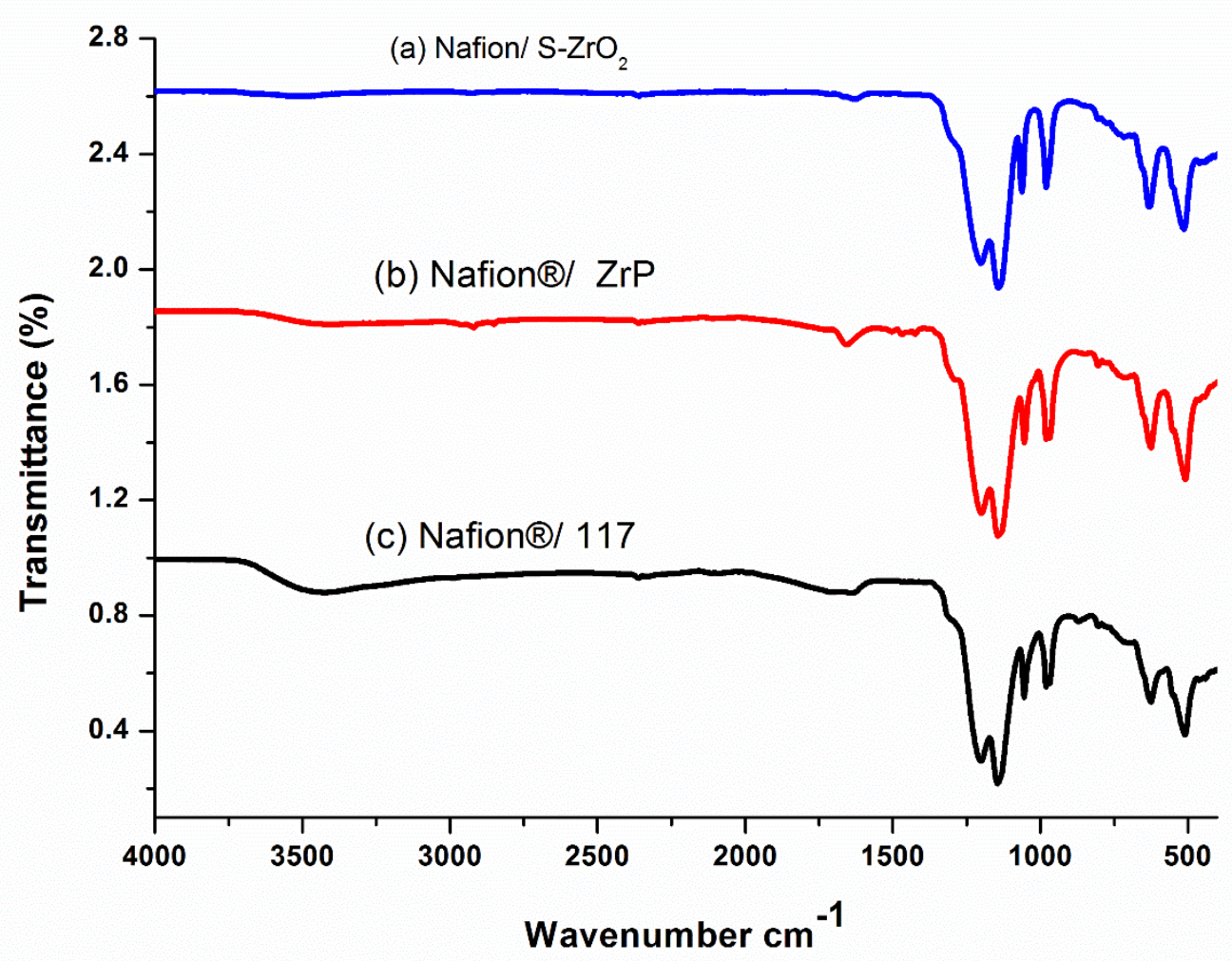

Figure 1: (a) $\mathrm{Nafion}^{\circledR} \mathrm{S}_{\mathrm{ZrO}}$, (b) $\mathrm{Nafion}^{\circledR} \mathrm{ZrP}$ nanocomposite membranes, and (c) Nafion ${ }^{\circledR} 117$ membranes' FTIR spectra.

\subsection{Membrane Morphology}

Scanning Electron Microscopy (SEM) was used to examine the morphology of Nafion ${ }^{\circledR} 117$ membranes, Nafion ${ }^{\circledR} / \mathrm{ZrP}$ membranes, and Nafion ${ }^{\circledR} / \mathrm{S} \mathrm{ZrO}_{2}$ nanocomposite membranes. Figure 2(a) demonstrates that the Nafion ${ }^{\circledR} 117$ membrane is dark in colour and free of nanoparticles. The Nafion ${ }^{\circledast / Z r P}$ nanocomposite membrane with evenly distributed $\mathrm{ZrP}$ nanoparticles and less agglomerates in the membrane matrix is shown in Figure 2(b), whereas the nanoparticles within the Nafion ${ }^{\circledR} / \mathrm{S}-\mathrm{ZrO}_{2}$ membrane were well scattered and agglomerated as represented in Figure 2(c). It's probable that this has something to do with the impregnation method, which was repeated five times to ensure that the nanoparticles were successfully impregnated. Using atomic force microscopy (AFM), the surface roughness of nanocomposite membranes was examined. Figure $3(a-b)$ shows that the surface roughness of $\mathrm{Nafion}{ }^{\circledast} / \mathrm{S}-\mathrm{ZrO} 2$ and $\mathrm{Nafion}{ }^{\circledR} / \mathrm{ZrP}$ nanocomposite membranes was $41.46 \mathrm{~nm}$ and $18.59 \mathrm{~nm}$, respectively, on topography images. The rougher surface of modified Nafion ${ }^{\circledR}$ nanocomposite membranes increases electrode contact [35]. The brightest areas in these images show the highest point of the membrane surface, while the dark areas show the valleys or membrane holes, as seen in Figure 3(a-b). The surface roughness of the Nafion ${ }^{\circledast / S}-\mathrm{ZrO}_{2}$ membrane was higher than that of the Nafion ${ }^{\otimes / Z r P}$ nanocomposite membranes, as numerous small peaks and valleys were replaced by many small ones, resulting in a smooth membrane surface (see Figure 3(a)) [36]. The membrane surface grew rougher because of the inclusion of hydrophilic $\mathrm{ZrP}$ nanoparticles within the membrane matrix, which increased surface roughness. 


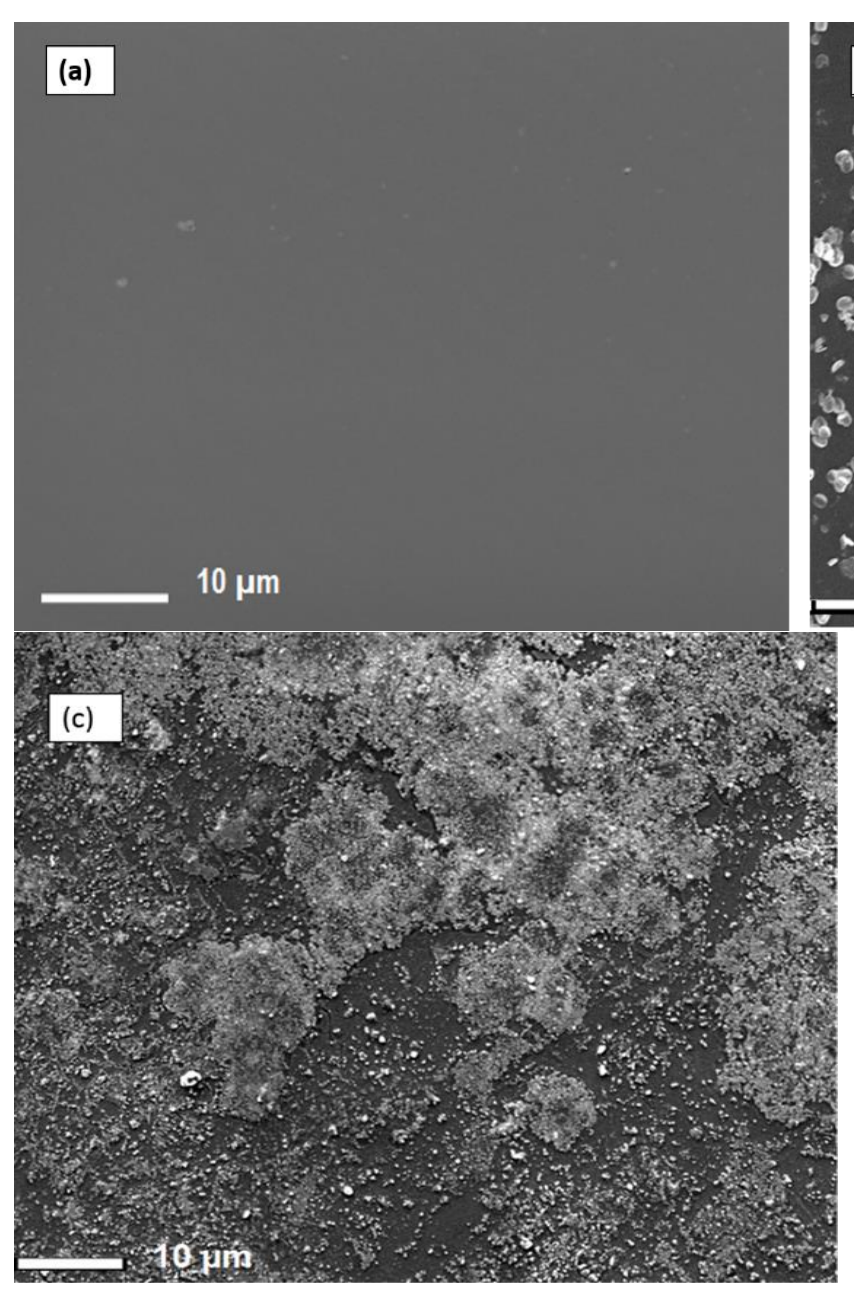

Figure 2. SEM micrograph of (a) of Nafion ${ }^{\circledR} 117$ membrane, (b) Nafion ${ }^{\circledR} \mathrm{ZrP}$ and (c) $\mathrm{Nafion}{ }^{\circledR} / \mathrm{S} \mathrm{ZrO}_{2}$ nanocomposite membranes.
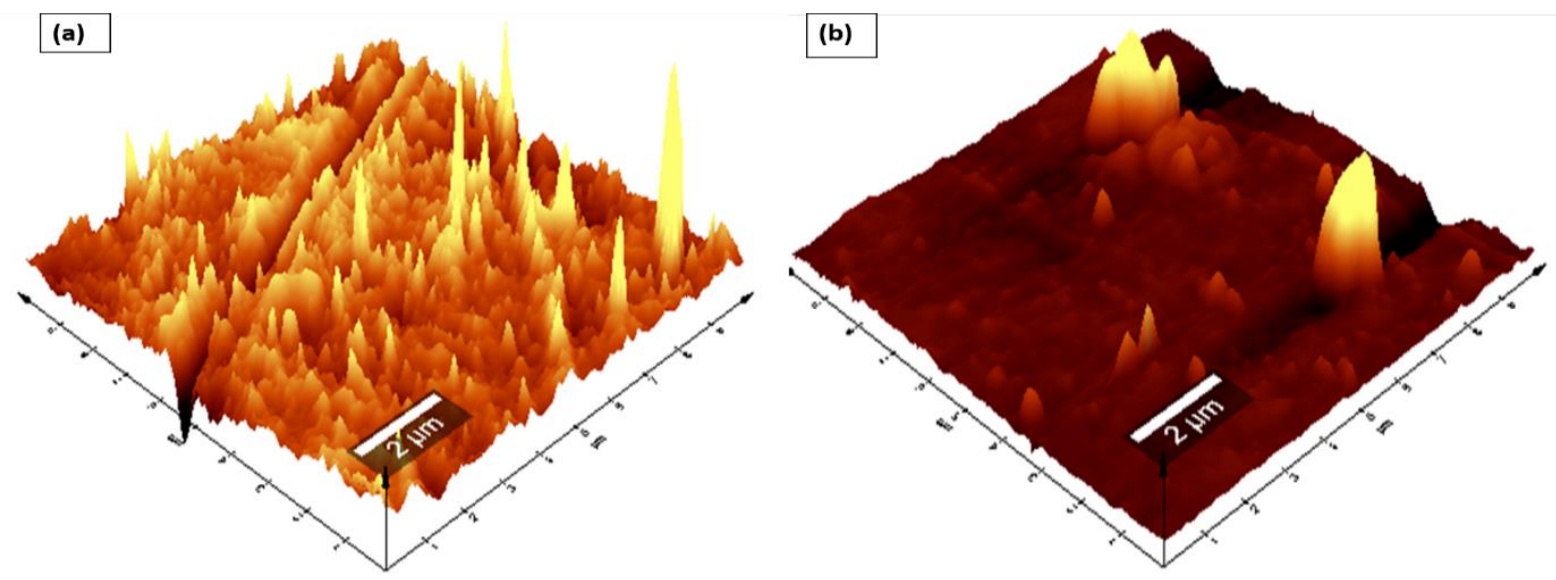

Figure 3. AFM (a-b) topography amplitude image of $\mathrm{Nafion}^{\circledR} / \mathrm{S}-\mathrm{ZrO}_{2}$ and $\mathrm{Nafion}{ }^{\circledR} / \mathrm{ZrP}$ nanocomposite membranes.

\subsection{Analysis of XRD Structure}

Figure 4 illustrates the XRD diffraction patterns of $\mathrm{Nafion}{ }^{\circledR} / \mathrm{S}-\mathrm{ZrO}_{2}$ nanocomposite membranes, commercial Nafion ${ }^{\circledR} 117$ membranes and Nafion ${ }^{\circledR} / \mathrm{ZrP}$ nanocomposite membranes, respectively. Figure $4(\mathrm{a}-\mathrm{b})$ reveals that the diffraction peaks of the $\mathrm{Nafion} \otimes / \mathrm{S}-\mathrm{ZrO}_{2}$ and Nafion ${ }^{\circledR} / \mathrm{ZrP}$ nanocomposite membranes are at $17^{\circ}$, which is slightly lower than that of the commercial membrane [37]. These can also be seen on the modified membranes' diffraction peaks at $39^{\circ}$ in Figure $3(a-b)$, which are slightly lower than the commercial membrane. This could be due to the well-distributed nanoparticles within the Nafion ${ }^{\circledR}$ matrix, as confirmed by SEM results, which reduces the intensity of the diffraction peak. 
Figure 3(c) indicates that the commercial Nafion ${ }^{\circledR} 117$ membrane only has two diffraction peaks at $17.5^{\circ}$ and $39^{\circ} 2 \theta$, this is due to the ionomer's perfluorocarbon chains being semicrystalline [38]. As a result of the broken hydrogen bonding within the Nafion ${ }^{\circledast} 117$ membrane, membranes incorporating nanoparticles tend to be amorphous with a decrease in crystallinity.

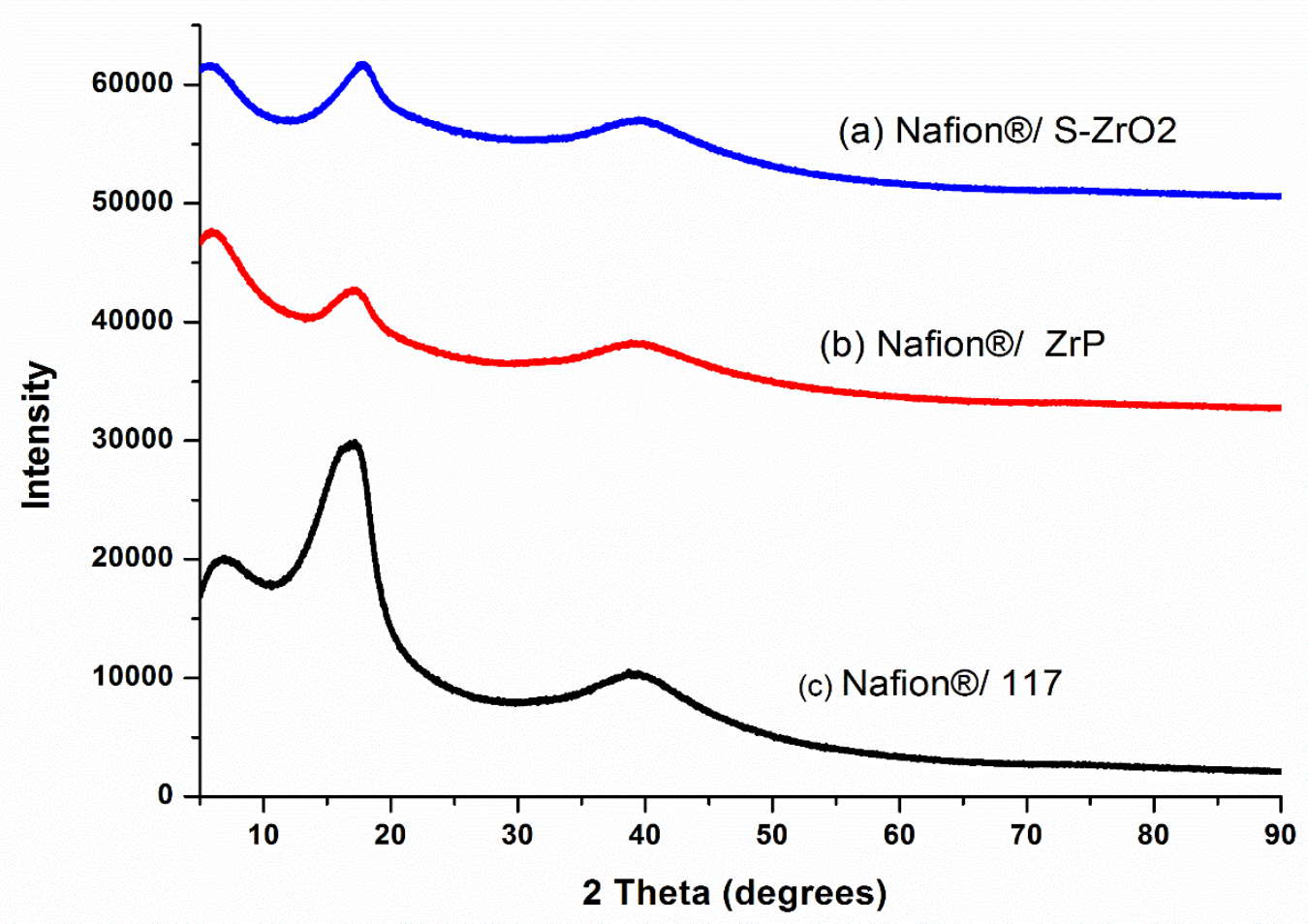

Figure 4. XRD patterns of (a) of $\mathrm{Nafion}^{\circledR} / \mathrm{S}^{-} \mathrm{ZrO}_{2}$ (b) $\mathrm{Nafion}^{\circledR} / \mathrm{ZrP}$ nanocomposite membranes and (c) $\mathrm{Nafion}^{\circledR} 117$ membrane.

\subsection{Thermo-gravimetric analysis (TGA)}

TGA was used to determine the derivative thermogravimetric (DTG) and thermal stability of modified membranes and Nafion ${ }^{\circledR} 117$ membranes. To assess the thermal properties of the membranes, thermal stability tests were carried out. Thermal stability is critical in defining the operating temperature of a fuel cell application. The TGA results of the Nafion ${ }^{\circledR} 117$ membrane, Nafion ${ }^{\otimes} / \mathrm{ZrP}$ and $\mathrm{Nafion}^{\otimes} / \mathrm{S}-\mathrm{ZrO}_{2}$ nanocomposite membranes follow a three-stage deterioration pattern, as shown in Figure 4. The first step corresponds to absorbed water evaporation, thermal degradation's second stage, the polymer matrix is then thermally oxidized in the third stage, respectively. The thermal stability of modified Nafion ${ }^{\circledR}$ membranes with $\mathrm{S}-\mathrm{ZrO}_{2}$ nanoparticles is better than that of modified Nafion ${ }^{\circledR}$ membranes with $\mathrm{ZrP}$ nanoparticles in Figure $4(\mathrm{a} \& \mathrm{~b})$, as it begins to lose weight at temperatures above $300^{\circ} \mathrm{C}$, whereas Nafion ${ }^{\circledast} / \mathrm{ZrP}$ begins to lose weight at temperatures below $150{ }^{\circ} \mathrm{C}$, this could be due to the well-distributed $\mathrm{S}-\mathrm{ZrO}_{2}$ in the form of small particles, as SEM results show. Furthermore, around $150^{\circ} \mathrm{C}$, Nafion ${ }^{\circledast} / \mathrm{ZrP}$ begins to lose weight, which corresponds to water adsorption as shown in Figure 4(b). The decomposition of the sulfonic acid groups causes the second weight loss at $340{ }^{\circ} \mathrm{C}$ [39]. The degradation of the polymer backbone chain may be the cause of the third weight loss at $570{ }^{\circ} \mathrm{C}$. This decreased thermal degradation could be attributed to the inorganic filler's composition and intimate interaction with the hydrophobic Nafion ${ }^{\circledast}$ backbone, as opposed to the commercial Nafion ${ }^{\circledR} 117$, which decomposed at $380^{\circ} \mathrm{C}$. [40]. Figure 4 (DTG insert) shows that the nanocomposite membranes have better heat stability about $340{ }^{\circ} \mathrm{C}$, but the Nafion ${ }^{\circledR} 117$ membrane has better thermal stability up to $240^{\circ} \mathrm{C}$ (DTG insert). This could be because of the inorganic nanofillers used in Nafion ${ }^{\circledR}$ membranes [41] that operate as a better insulator and mass transport barrier to the volatile compounds produced during decomposition, as a result, it's ideal for fuel cell applications. Due to the evaporation of adsorption bound 
water to the sulfonic groups, the commercial Nafion ${ }^{\circledR} 117$ membrane in Figure 4(c) initially loses weight at $100^{\circ} \mathrm{C}$. [8]. At $380^{\circ} \mathrm{C}$, the second weight loss could be attributed to sulfonic group degradation [39]. The degradation of the polymer backbone chain may be the cause of the third weight loss at $550{ }^{\circ} \mathrm{C}$ [42]. We may conclude that reducing the mobility of the Nafion ${ }^{\circledast}$ chain delays the initial weight loss and thermal degradation of modified membranes compared to unmodified membranes.

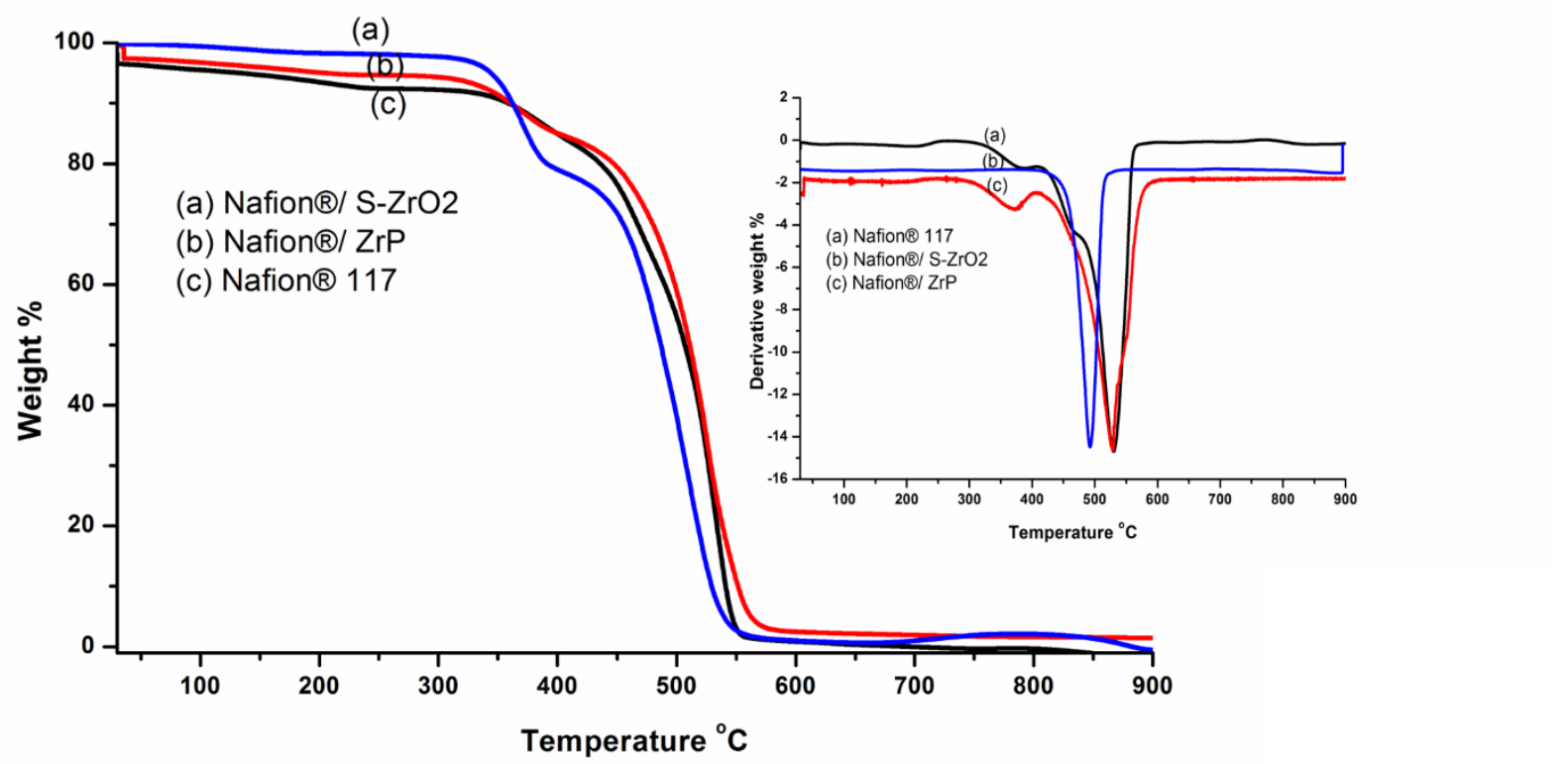

Figure 3. The TGA and DTG of (a) Nafion ${ }^{\circledR} / \mathrm{S}-\mathrm{ZrO}_{2}$, (b) Nafion ${ }^{\circledR} / \mathrm{ZrP}$ nanocomposite membranes and (c) Nafion ${ }^{\circledR} 117$ membrane.

\subsection{Tensile tests}

Tensile tests were used to determine the membrane's mechanical strength and the findings are shown in Figure 5. Figure 5(a-c) shows the stress-strain curves of the Nafion ${ }^{\circledR}$ 117 membrane, Nafion ${ }^{\otimes} / \mathrm{ZrP}$ and $\mathrm{Nafion} \otimes / \mathrm{S} \mathrm{ZrO}_{2}$ nanocomposite membrane at 20, 30, and $40 \mathrm{~mm} / \mathrm{min}$ [43-45]. The elasticity and flexibility of the membranes at 0.6 stress versus strain are demonstrated at a stress rate of $20 \mathrm{~mm} / \mathrm{min}$. The modified membrane with inorganic nanofiller improves the tensile strength within the membrane, as shown in Figure 5(b-c), which could be attributed to the nanofiller's incorporation into the Nafion ${ }^{\circledR}$ matrix. When $\mathrm{ZrP}$ was added to $\mathrm{Nafion}^{\circledR}$, the tensile stress was lowered to $1300 \mathrm{kPa}$ at a strain rate of $40 \mathrm{~mm} / \mathrm{min}$, this could be due to the small agglomeration of $\mathrm{ZrP}$ nanoparticles in the Nafion ${ }^{\circledR}$ matrices, which resulted in the modified membrane brittlely fractured, whereas the Nafion ${ }^{\otimes} / \mathrm{S}-\mathrm{ZrO}_{2}$ shows a greater tensile stress of $2630 \mathrm{kPa}$ at the same strain rate, this could be attributed to well-distributed $\mathrm{S}-\mathrm{ZrO}_{2}$ with minimal agglomeration, as seen by SEM and AFM data, as aggregated nanoparticles may have an impact on mechanical strength. Furthermore, good contact between the membrane and nanoparticles would improve nanocomposite reinforcement and fuel cell durability, which is a more important requirement for the production and operating process. Figure $5(a-c)$ shows the Nafion ${ }^{\circledR /}$ $\mathrm{S}-\mathrm{ZrO}_{2}$ tensile stress-strain curves, which demonstrate a significant improvement as it achieved a tensile stress of $2630 \mathrm{kPa}$ at 20,30 , and $40 \mathrm{~mm} / \mathrm{min}$, which is twice that of Nafion ${ }^{\circledR} / \mathrm{ZrP}(1630 \mathrm{kPa})$ and Nafion ${ }^{\circledR} 117(990 \mathrm{kPa})$. The enhanced tensile stress of Nafion ${ }^{\circledR /}$ $\mathrm{S}-\mathrm{ZrO}_{2}$ membranes may be related to the presence of ammonia sulphate ions within the membrane, which promotes the movement and flexibility of polymer chains, resulting in mechanical strength suitable for fuel cell applications. Furthermore, the nanocomposite membrane had a higher stress-strain than the Nafion ${ }^{\circledR} 117$ membrane. Overall, the results demonstrated that adding sulfated zirconia to the Nafion ${ }^{\circledR}$ membrane improved the stress-strain properties, which are good DMFC features [46]. 

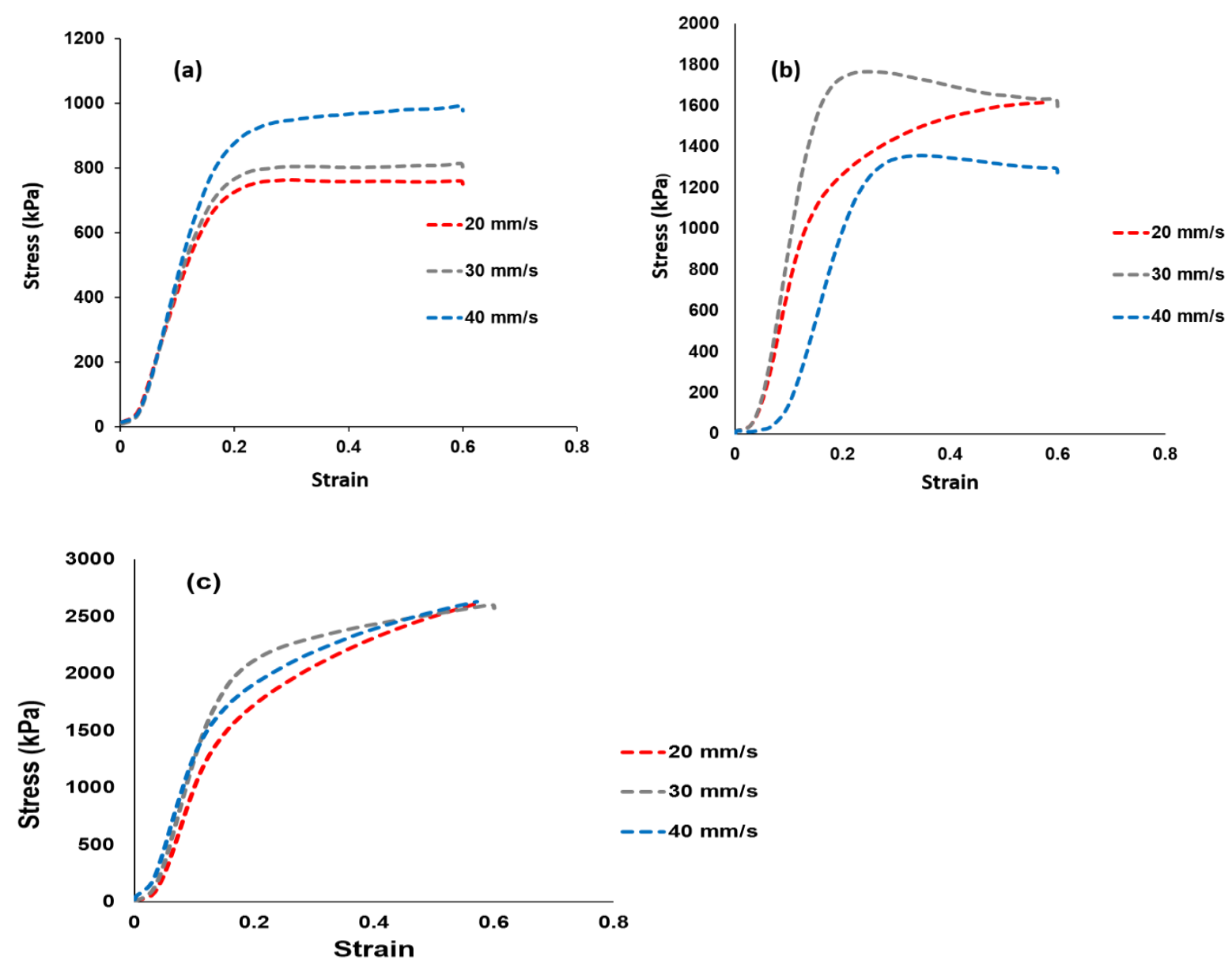

Figure 4. Mechanical tensile tests results of (a) Nafion ${ }^{\circledR} 117$ membrane, (b) Nafion ${ }^{\circledR} / \mathrm{ZrP}$ and (c) $\mathrm{Nafion}^{\circledR} / \mathrm{S} \mathrm{ZrO}_{2}$ nanocomposite membranes shows stress versus strain ratio curve.

3.6 Methanol permeability

At different methanol concentrations $(2 \mathrm{M}$ and $5 \mathrm{M})$ and temperatures of $30^{\circ} \mathrm{C}, 60{ }^{\circ} \mathrm{C}$ and $80{ }^{\circ} \mathrm{C}$, the methanol permeability of Nafion ${ }^{\circledR} 117$ membrane, Nafion ${ }^{\circledast /} \mathrm{ZrP}$ and Nafion ${ }^{\circledR} / \mathrm{S}-\mathrm{ZrO}_{2}$ nanocomposite membrane was measured. There was no methanol crossover seen for all membranes at varied temperatures and lower concentrations of $2 \mathrm{M}$ methanol [47] as shown in Figure 6. Figure 6 shows that a membrane's methanol crossover is influenced by its affinity for both water and methanol, as well as the amount of empty sp8ace within the membrane [48]. However, because of the nanocomposite's dense internal structure and greater filler loading, the methanol molecules have a longer diffusion path, as a result, the permeability of methanol in nanocomposite membranes is decreasing. Furthermore, because methanol permeability is caused by the movement of molecules across the membrane, the size of the transport molecules must be considered while analysing methanol permeability. According to Yang et al., lowering the methanol concentration lowers the methanol crossover because the concentration gradient is lower [49]. As a result, a higher concentration of $5 \mathrm{M}$ methanol solution was used in this study. At $60{ }^{\circ} \mathrm{C}$, the methanol permeability of $\mathrm{Nafion}^{\circledast} 117$ membrane, Nafion ${ }^{\otimes} / \mathrm{ZrP}$ and Nafion ${ }^{\circledast} / \mathrm{S}-\mathrm{ZrO}_{2}$ nanocomposite membranes was $8.84 \times 10^{-7} \mathrm{~cm}^{2} / \mathrm{s}, 0 \mathrm{~cm}^{2} / \mathrm{s}$ and $0 \mathrm{~cm}^{2} / \mathrm{s}$ (no crossover), respectively, as shown in Figure 6. The methanol permeability of modified and unmodified Nafion ${ }^{\circledR}$ membranes increases as the temperature rises, as shown in Figure 6 . When the temperature is raised to $80{ }^{\circ} \mathrm{C}$, the results demonstrate that nanocomposite membranes have a lower methanol penetration, indicating that water permeation is greater than methanol permeation at high temperatures. This is because methanol molecules are larger than water molecules, they are more likely to be obstructed by space limits inside the membrane structure [48]. As shown in Figure 6, the methanol permeability of Nafion ${ }^{\circledR} 117$, Nafion ${ }^{\circledR} / \mathrm{ZrP}$ and Nafion ${ }^{\circledR} / \mathrm{S}-\mathrm{ZrO}_{2}$ nanocomposite membranes is $1.99 \times 10^{-}$ 
${ }^{6} \mathrm{~cm}^{2} / \mathrm{s}, 1.55 \times 10^{-6} \mathrm{~cm}^{2} / \mathrm{s}$, and $1.50 \times 10^{-7} \mathrm{~cm}^{2} / \mathrm{s}$, respectively. The nanocomposite membrane had a lower methanol permeability than commercial Nafion ${ }^{\circledR} 117$, which was owing to the addition of $\mathrm{ZrP}$ and $\mathrm{S}-\mathrm{ZrO}_{2}$ to $\mathrm{Nafion}^{\circledR} 117$, which improved the barrier properties of Nafion ${ }^{\circledast}$ membrane towards methanol. Furthermore, by preventing methanol from migrating through the membrane, the well-dispersed nanoparticles may limit methanol crossing [50]. Because methanol crossover can affect fuel efficiency, a reduced or low methanol crossover is critical in DMFC applications. In addition, modified Nafion ${ }^{\circledR}$ nanocomposite membranes appear to be potential electrolytes for use in fuel cells.

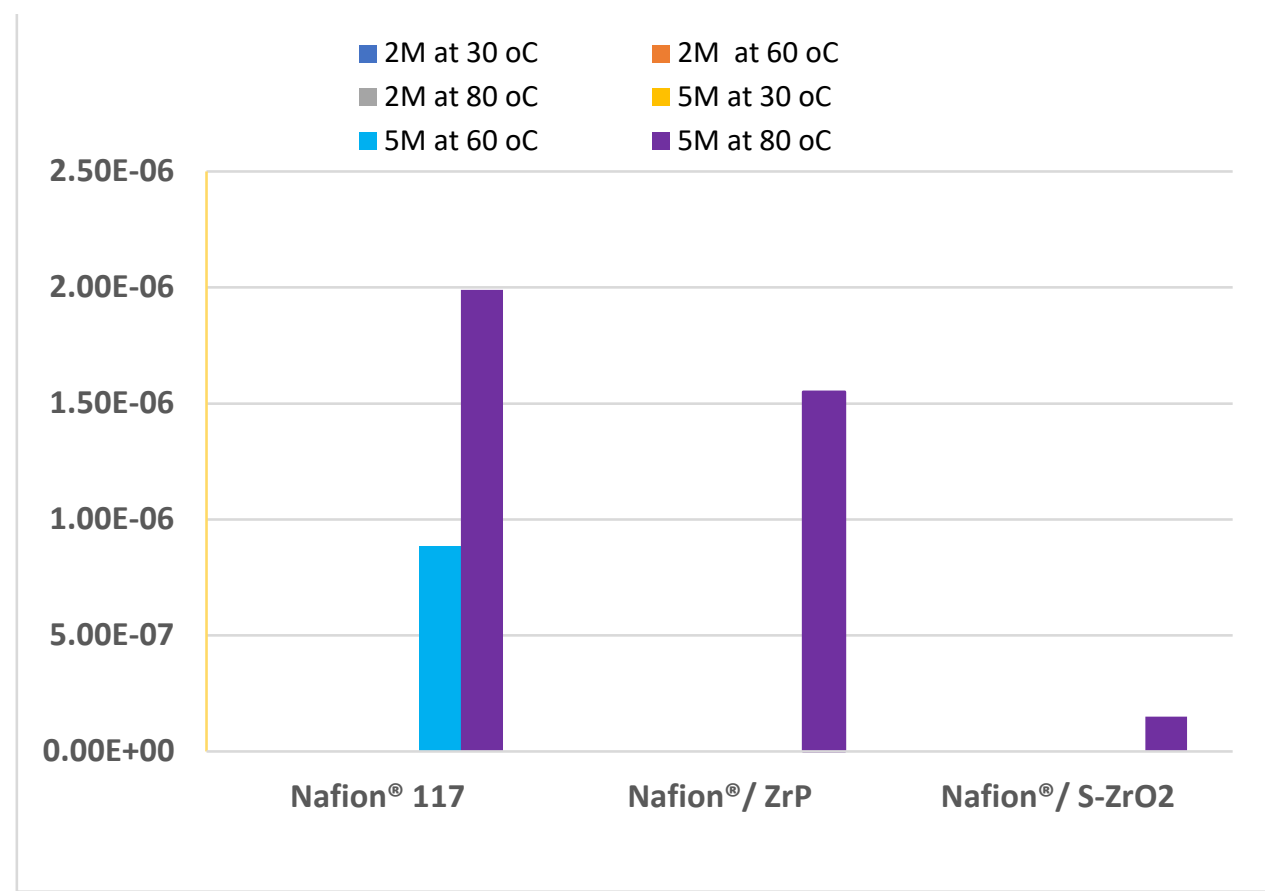

Figure 5. The methanol permeability of $\mathrm{Nafion}^{\circledast} 117, \mathrm{Nafion}^{\circledast} / \mathrm{ZrP}$ and $\mathrm{Nafion}^{\circledast} / \mathrm{ZrO}_{2}$ nanocomposite membranes at $5 \mathrm{M}$ and $2 \mathrm{M}$ concentration.

3.7 Water contact angle, Water uptake, dimensional swelling ratio, Ion exchange capacity and proton conductivity measurement.

In fuel cell applications, water wettability within the membrane matrix is critical because it promotes protonic conductivity of the membrane by allowing protons to move through it [37]. Figure 7(a) shows how contact angle was used to determine water wettability. A polymer with a smaller contact angle is more hydrophilic, while high contact angle indicates a more hydrophobic polymer. Because of its hydrophobic nature, the commercial Nafion ${ }^{\circledR} 117$ membrane attained a contact angle larger than $90^{\circ}$, as illustrated in Figure 7 (a) [10]. As shown in Figure $7(\mathrm{a})$, the contact angle of $\mathrm{Nafion}{ }^{\circledast} / \mathrm{S}-\mathrm{ZrO}_{2}$ and Nafion ${ }^{\circledR} / \mathrm{ZrP}$ nanocomposite membranes is smaller, ranging from $80^{\circ}$ to $68^{\circ}$, this could be owing to the introduction of inorganic material with a hydrophilic property that holds water [51]. In addition, the modified membranes demonstrate that inorganic material impregnating the Nafion ${ }^{\circledR}$ membrane surface results in hydrophilicity [52]. The hydrophobicity of Nafion ${ }^{\circledR}$ membranes is increased when they are treated with hydrophobic nanoparticles. The dimensional swelling ratio at $30^{\circ} \mathrm{C}, 60^{\circ} \mathrm{C}$ and $80^{\circ} \mathrm{C}$ shows a slightly increased with the increases in temperature as shown in Figure $7 \mathrm{~b}$. However, when Nafion ${ }^{\circledR} / \mathrm{ZrP}$ nanocomposite membrane was soaked at higher temperature of $80{ }^{\circ} \mathrm{C}$, a higher dimensional swelling ratio of $35 \%$ was obtained when compared with $\mathrm{Nafion}{ }^{\circledast} 117$ membrane (29\%) and Nafion ${ }^{\circledast} / \mathrm{S}-\mathrm{ZrO}_{2}$ nanocomposite membranes (33\%). Moreover, when temperature increases also increases the dimensional stability and water uptake of the membranes.

Figure 7(c) shows the water uptake of Nafion ${ }^{\circledR} 117$ membranes, Nafion ${ }^{\circledast / Z r P ~ n a n o-~}$ composite membranes, and Nafion ${ }^{\circledR} / \mathrm{S}-\mathrm{ZrO}_{2}$ nanocomposite membranes at $30^{\circ} \mathrm{C}, 60{ }^{\circ} \mathrm{C}$, 
and $80{ }^{\circ} \mathrm{C}$. As the temperature rise from $30^{\circ} \mathrm{C}$ to $80^{\circ} \mathrm{C}$, all membranes exhibit an increase in water uptake [53].. At $80{ }^{\circ} \mathrm{C}$, the Nafion ${ }^{\circledR} / \mathrm{ZrP}$ and $\mathrm{Nafion}^{\circledR} / \mathrm{S}-\mathrm{ZrO}_{2}$ nanocomposite membrane had the highest water uptake of $49 \%$ and $47 \%$, compared to $34 \%$ for Nafion ${ }^{\circledR} 117$ membranes as shown in Figure 7(c). This could be due to the use of hydrophilicity of adsorption acidic materials ZrP nanoparticles, which help the membranes retain water [54, 55]. Moreover, this could be attributed to an excellent distribution of hygroscopic $\mathrm{S}-\mathrm{ZrO}_{2}$ nanoparticles that hold water within the membrane matrix. Table 1 shows that the modified membrane with $\mathrm{ZrP}$ and $\mathrm{S}-\mathrm{ZrO}_{2}$ nanoparticles demonstrated enhanced water uptake at a higher temperature of $60^{\circ} \mathrm{C}$ than the unmodified membrane. This could be attributed to the hydrophilic character of acidic nanoparticles, which raises the acidity and surface areas of nanoparticles integrated into the Nafion ${ }^{\circledR}$ matrix, as well as the existence of a high concentration of polymer-filler interfaces, which increases the free volume [56]. Furthermore, nanoparticle impregnation causes clusters in the pore of the Nafion ${ }^{\circledR}$ membrane, resulting in the nanocomposite membrane's higher water uptake $[37,57,58]$.This conclusion is consistent with the hydrophobic site's reduced contact angle in Figure 7(a).

The proton conductivity and IEC of Nafion ${ }^{\circledR} 117$ membranes, Nafion ${ }^{\circledR} / \mathrm{ZrP}$ nanocomposite membranes, and $\mathrm{Nafion}{ }^{\circledR} / \mathrm{S}-\mathrm{ZrO}_{2}$ nanocomposite membranes are shown in Figure 7(d). The Nafion ${ }^{\circledR} / \mathrm{ZrP}$ and Nafion ${ }^{\circledR} / \mathrm{S}-\mathrm{ZrO}_{2}$ nanocomposite membranes had an IEC of $1.46 \mathrm{meg} / \mathrm{g}$ and $1.3 \mathrm{meg} / \mathrm{g}$ greater than the Nafion ${ }^{\circledR} 117$ membrane's IEC of $0.93 \mathrm{meg} / \mathrm{g}$. This could be because acidic nanoparticles are impregnated into the Nafion ${ }^{\circledR}$ membrane, which provides the membrane with a strong acid site [55], with the inclusion of sulfate ions as proton exchange sites within the Nafion ${ }^{\circledR}$ matrix [59]. The nanocomposites' IEC rises as more nanoparticles are incorporated into the membrane. The proton conductivity of a polymer electrolyte membrane in a fuel cell is the most essential factor that influences its performance. At room temperature, the proton conductivity of the $\mathrm{Nafion}{ }^{\circledR} / \mathrm{ZrP}$ nanocomposite membrane was $0.031 \mathrm{Scm}^{-1}$, compared to $7.89 \mathrm{Scm}^{-1}$ and $0.113 \mathrm{Scm}^{-1}$ for the Nafion ${ }^{\circledR} / \mathrm{S}-\mathrm{ZrO}_{2}$ nanocomposite membranes and $\mathrm{Nafion}^{\circledR} 117$ membrane, it's possible that zirconia phosphate nanoparticles within the membranes are causing this decrease in proton conductivity $[11,60]$ because their ionic activity and water mobility are both affected by high temperatures. Furthermore, as the length of the hydrophilic block rises, so does their ionic conductivity. Furthermore, sulphating zirconia nanoparticles with $\mathrm{NH}_{3} \mathrm{SO}_{4}$ acid improved the proton conductivity of the nanocomposite membranes by promoting the migration of sulfonated groups to form cluster aggregates via the strong electrostatic contacts of the $\mathrm{Na}+$ counter ions.

Table 1.The proton conductivity and IEC of Nafion ${ }^{\circledR} 117$, Nafion ${ }^{\circledR} / \mathrm{ZrP}$ and $\mathrm{Nafion}^{\circledR} / \mathrm{S}-\mathrm{ZrO}_{2}$ nanocomposite membranes

\begin{tabular}{|l|l|l|l|}
\hline Membranes & Nafion ${ }^{\circledR} 117$ & Nafion ${ }^{\circledR} / \mathrm{ZrP}$ & Nafion ${ }^{\circledR} / \mathrm{S}-\mathrm{ZrO}_{2}$ \\
\hline $\begin{array}{l}\text { IEC }(\mathrm{meq} / \mathrm{g}) \\
\text { Proton conductivity }(\mathrm{S} / \mathrm{cm})\end{array}$ & 0.93 & 1.46 & 1.3 \\
\hline Water uptake $\%\left(30^{\circ} \mathrm{C}\right)$ & 0.113 & 0.031 & 7.89 \\
\hline Water uptake $\%\left(60^{\circ} \mathrm{C}\right)$ & 30 & 43 & 40 \\
\hline Water uptake $\%\left(80^{\circ} \mathrm{C}\right)$ & 32 & 44 & 44 \\
\hline
\end{tabular}


(a)
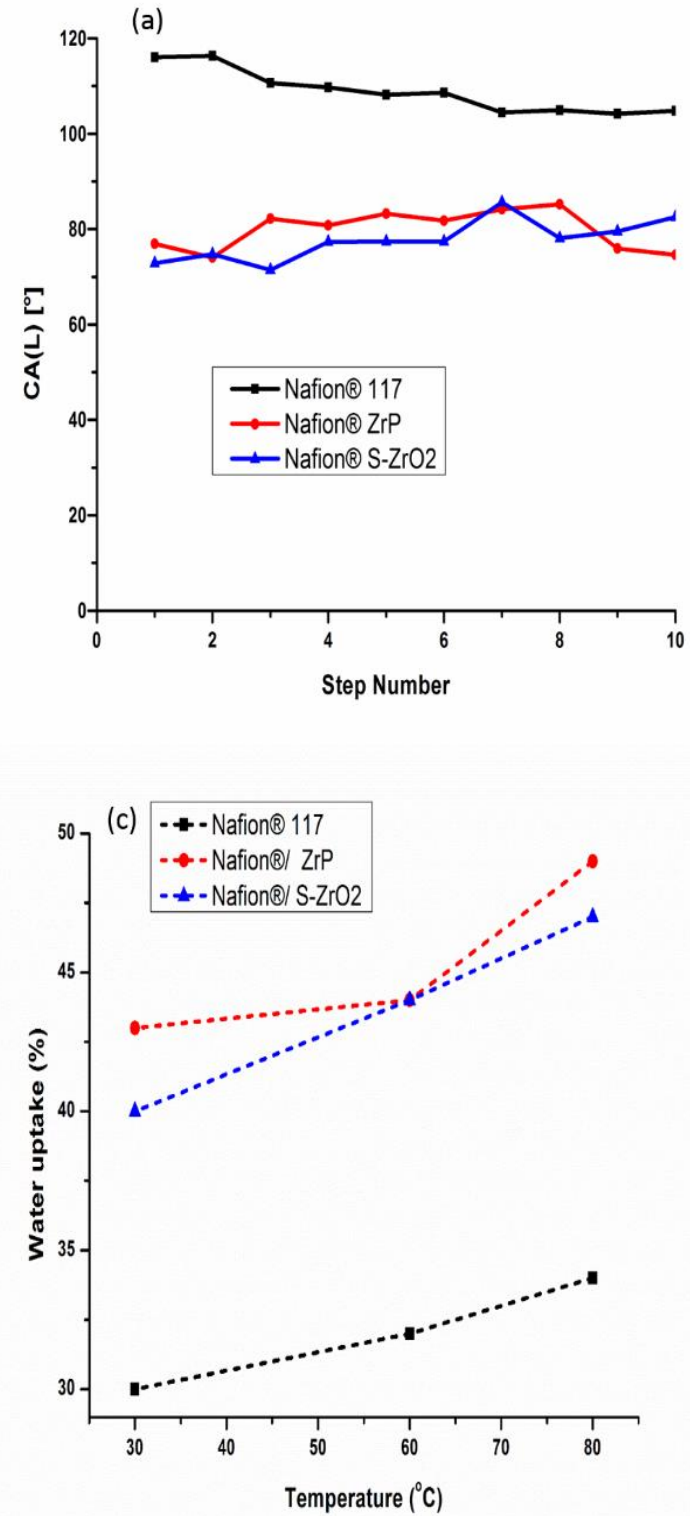
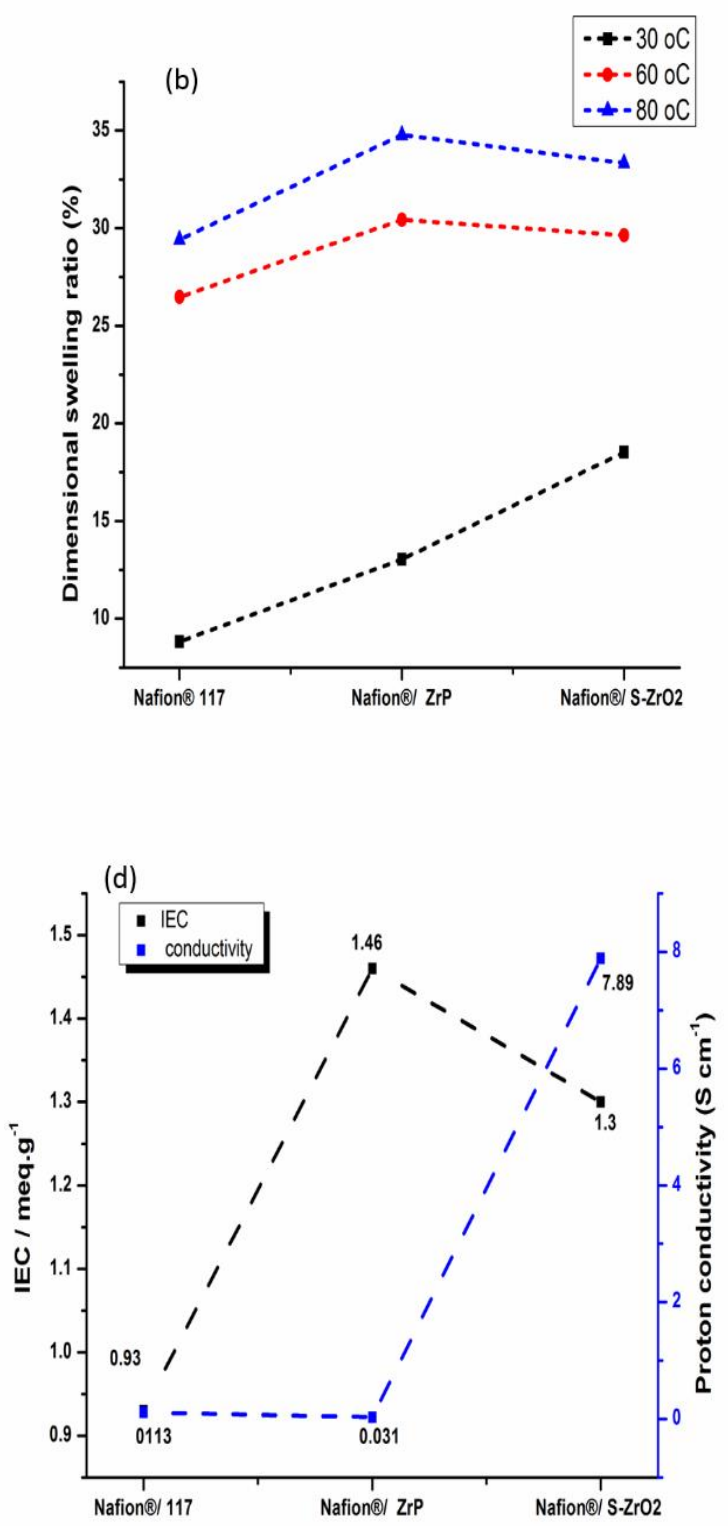

Figure 6. Contact angle(a), linear expansion (b), water uptake (c) and Ion exchange capacity and proton conductivity measurement (d) of Nafion ${ }^{\circledR} 117$ membrane, Nafion ${ }^{\circledast / Z r P}$ and Nafion ${ }^{\circledR} / \mathrm{S}-\mathrm{ZrO}_{2}$ nanocomposite membranes.

\subsection{Fuel cell performance}

Single cell DMFC tests were done at $60^{\circ} \mathrm{C}$ to further confirm the influence of acidic nanoparticles on the electrochemical performance of commercial Nafion ${ }^{\circledR} 117$ membrane. The polarization and power density graphs for DMFCs are shown in Figure 8. The peak density of the Nafion ${ }^{\circledast / Z r P}$ nanocomposite membrane is $206.79 \mathrm{~mW} \mathrm{~cm}^{-2}$, which is greater than the Nafion ${ }^{\circledast} / \mathrm{S}_{-} \mathrm{ZrO}_{2}$ nanocomposite membrane $\left(183 \mathrm{~mW} \mathrm{~cm}^{-2}\right)$ and $\mathrm{Nafion}^{\circledR} 117 \mathrm{mem}$ brane $\left(126.04 \mathrm{~mW} \mathrm{~cm}^{-2}\right)$ at the current densities of $189 \mathrm{~mA} \mathrm{~cm}^{-2}$. Therefore, Nafion ${ }^{\circledR} 117$ membrane incorporated with $5 \% \mathrm{ZrP}$ obtained the highest power density $\left(145 \mathrm{~mW} \mathrm{~cm}^{-2}\right)$ than commercial membrane, with current density of $350 \mathrm{~mA} \mathrm{~cm}^{-2}$ as shown in Figure 8(a). This may be due to the nanoparticles that well deposited within the membrane pores, that are good in water retention and enhance the conductivity of modified membrane [61]. The best fuel cell performance is ascribed to the better water retention capabilities of the composite membrane with acidic nanoparticles filler. Furthermore, the increased power density could be attributable to the use of $\mathrm{ZrP}$, which reduces the ohmic resistance of the Nafion ${ }^{\circledR}$ membrane [62]. The Nafion ${ }^{\circledast} / \mathrm{S}-\mathrm{ZrO}_{2}$ nanocomposite membrane's superior 
performance in DMFC is attributed to its proton conductivity and decreased methanol permeability. The modified membrane had a higher voltage than the commercial membrane, as seen in Figure 8(b), when compared to the Nafion ${ }^{\circledR} 117$ membrane $(0.58 \mathrm{~V})$, $\mathrm{Nafion}^{\circledR} / \mathrm{ZrP}(0.91 \mathrm{~V})$ and $\mathrm{Nafion}^{\circledR} / \mathrm{S}-\mathrm{ZrO}_{2}(0.85 \mathrm{~V})$ nanocomposite membranes at current densities of $200 \mathrm{mAcm}^{-2}$. This indicates that the nanocomposite membranes are good barrier to prohibit the crossover of both the fuel and the oxidant. Furthermore, this could be attributed to a larger percentage of $\mathrm{ZrP}$ in the Nafion matrix membrane. The improvement in voltage and current density can be seen by the decreased weight percent incorporation. This could be owing to the nanoparticles that have been well deposited within the membrane pores, which aid in water retention and improve the modified membrane's conductivity. [61]. The Nafion ${ }^{\circledR} / \mathrm{ZrP}$ nanocomposite membrane $(0.48 \mathrm{~V})$ displays a modest drop in voltage at current densities of $350 \mathrm{mAcm}^{-2}$. Although Nafion ${ }^{\circledR} / \mathrm{ZrP}$ outperformed the Nafion ${ }^{\circledR} / \mathrm{S}-\mathrm{ZrO}_{2}$ nanocomposite membranes in terms of fuel cell performance, but Nafion ${ }^{\circledR} / \mathrm{S}-\mathrm{ZrO}_{2}$ nanocomposite membrane shows the long-term stability. Therefore, we can conclude that the Nafion ${ }^{\circledR} / \mathrm{S}-\mathrm{ZrO}_{2}$ nanocomposite membrane herein are reasonably decent and appropriate for DMFC application. Also, these results suggest that modified membranes show great potential in direct methanol fuel cells.

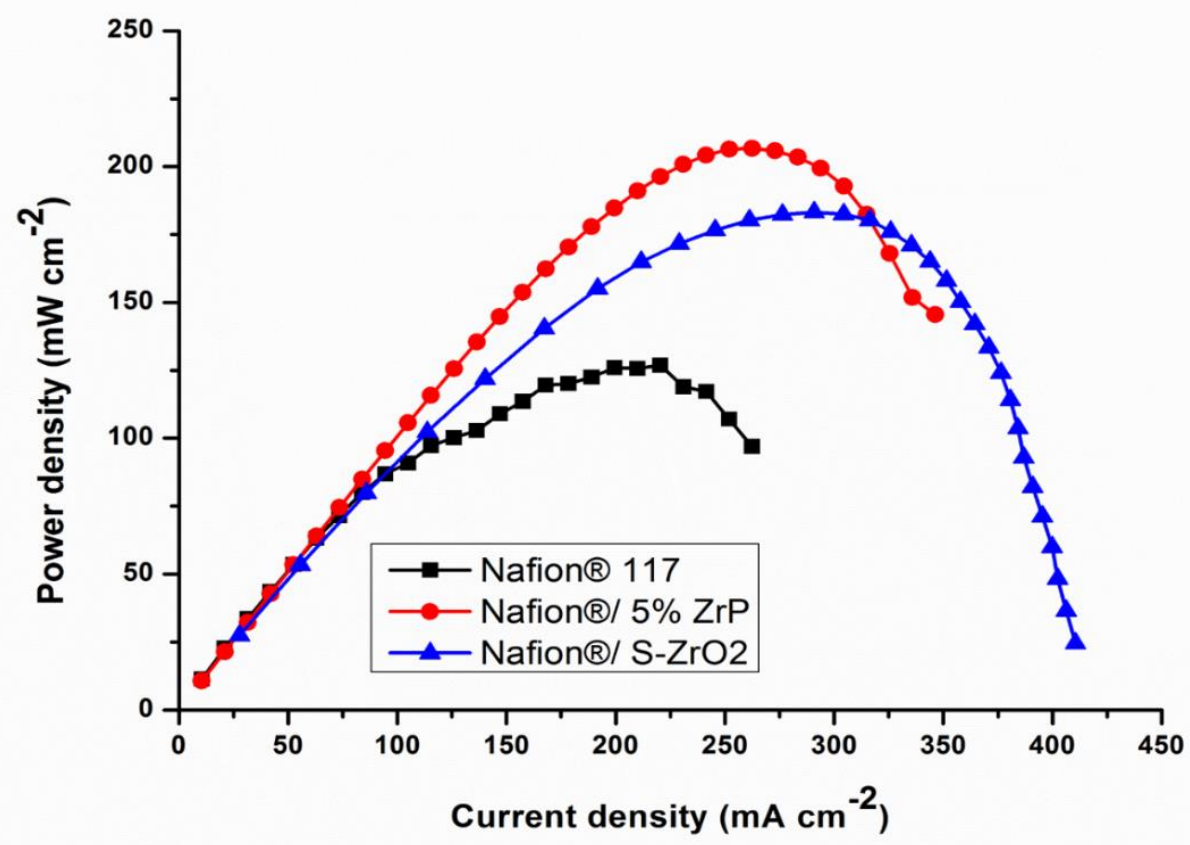




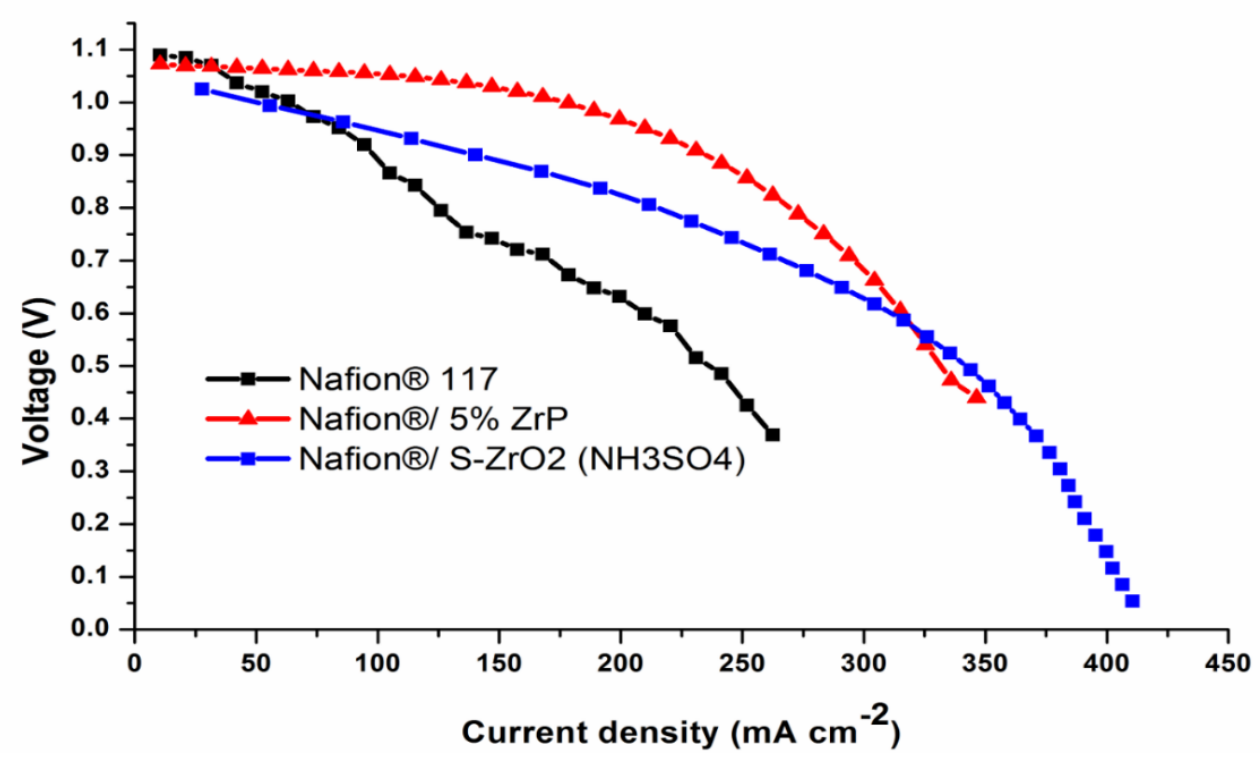

Figure 7. (a \&b) DMFC polarization of $\mathrm{Nafion}^{\circledR} 117$ membrane, Nafion ${ }^{\circledR} / \mathrm{ZrP}$ and Nafion ${ }^{\circledR} / \mathrm{S}-\mathrm{ZrO}_{2}$ nanocomposite membranes obtained at $60^{\circ} \mathrm{C}$.

\section{Discussion}

The impregnation approach was used to successfully construct the Nafion ${ }^{\otimes} / \mathrm{ZrP}$ and Nafion ${ }^{\circledR / S}$ S-ZrO2 nanocomposite membranes with low methanol permeability and high proton conductivity. Because of the nature of an inorganic filler and their tight interaction with the hydrophobic Nafion ${ }^{\circledR}$ backbones, the thermal stability of the nanocomposite membrane began to degrade at a high temperature of $450{ }^{\circ} \mathrm{C}$. Furthermore, when compared to Nafion ${ }^{\circledR} 117$ membrane, water uptake, IEC and linear expansion of nanocomposite membranes were improved. The results revealed that the nanocomposite membranes obtained lower water contact angle than the commercial Nafion ${ }^{\circledR}$ membrane. Moreover, the results shows that the incorporating of $\mathrm{S}-\mathrm{ZrO}_{2}$ in Nafion ${ }^{\circledR}$ membrane enhance the conductivity while compared with modified membrane by $\mathrm{ZrP}$ nanoparticles. The results demonstrate a decrease in methanol permeability on modified Nafion ${ }^{\circledR}$ membrane, at a higher temperature of $80^{\circ} \mathrm{C}$ and a $5 \mathrm{M}$ methanol concentration when compared to Nafion ${ }^{\circledR}$ 117 membrane, which may be due to the incorporation of inorganic components within the membranes. The improved membrane's lower methanol permeability and strong proton conductivity resistance further verified its feasibility for use in fuel cells. The inclusion of $\mathrm{ZrP}$ and $\mathrm{S}-\mathrm{ZrO}_{2}$ in the membranes was confirmed by SEM and FTIR findings, which also improved water uptake. At $80^{\circ} \mathrm{C}$, the Nafion ${ }^{\circledast} / \mathrm{ZrP}$ and Nafion ${ }^{\circledast} / \mathrm{S}-\mathrm{ZrO}_{2}$ nanocomposite membranes' water uptake and swelling ratio ranged from $47 \%$ to $49 \%$ and 33 to $35 \%$, respectively. These findings suggest that nanocomposite membrane have higher IEC with improved conductivity. The power density of the Nafion ${ }^{\circledast / Z r P}\left(206.79 \mathrm{~mW} \mathrm{~cm}^{-2}\right)$ and Nafion ${ }^{\otimes /} / \mathrm{S}-\mathrm{ZrO} 2\left(183 \mathrm{~mW} \mathrm{~cm}^{-2}\right)$ nanocomposite membranes was higher than that of the commercial Nafion ${ }^{\circledR} 117$ membranes $\left(126 \mathrm{~mW} \mathrm{~cm}^{-2}\right)$. The Nafion ${ }^{\circledR} / \mathrm{S}-\mathrm{ZrO}_{2}$ nanocomposite membrane produced a maximum power density of $188.6 \mathrm{mWcm} 2$ and an OCV of $0.98 \mathrm{~V}$, indicating that the Nafion ${ }^{\circledast} / \mathrm{S}_{-} \mathrm{ZrO}_{2}$ nanocomposite membranes are promising for fuel cells. The results also showed that modified membrane with $\mathrm{ZrP}$ nanoparticles obtained the highest fuel cell performance at maximum power density of $188.6 \mathrm{mWcm} 2$ and an OCV of $0.98 \mathrm{~V}$ with the short life when compared with $\mathrm{Nafion}{ }^{\circledast} / \mathrm{S}-\mathrm{ZrO}_{2}$ which attains a longlife in the fuel cell performance. 
Supplementary Materials: All materials for this study are presented in this article

Author Contributions: Conceptualization, R.S, and T.M..; methodology, F.N; R.S; and P.M;.; software, F.N; R.S; and P.M;.; validation, F.N; R.S; and P.M..; formal analysis, F.N; R.S; and P.M.; investigation, F.N; R.S; and P.M.; resources, F.N; and R.S.; data curation, R.S.; writing-original draft preparation, R.S.; writing - review and editing, F.N and R.S;.; visualization, F.N and R.S.; supervision, F.N; and T.M;.; project administration, R.S; funding acquisition, R.S. All authors have read and agreed to the published version of the manuscript.

Funding: Financial support was provided by the University of South Africa (AQIP) and the National Research Funding Agency (NRF). UNISA for SEM and CSIR for the methanol crossover results are also acknowledged.

Data Availability Statement: All materials for this study are presented in this article and available on request to the corresponding authors

Acknowledgments: The authors would like to thank the University of South and University of Johannesburg for testing facilities

Conflicts of Interest: The authors declare no conflict of interest. The funders had no role in the design of the study; in the collection, analyses, or interpretation of data; in the writing of the manuscript, or in the decision to publish the results.

\section{References}

1. Kreuer, K., On the development of proton conducting polymer membranes for hydrogen and methanol fuel cells. Journal of membrane science, 2001. 185(1): p. 29-39.

2. Anderson, A.B., et al., Activation energies for oxygen reduction on platinum alloys: Theory and experiment. The Journal of Physical Chemistry B, 2005. 109(3): p. 1198-1203.

3. Bauer, I., et al., Shuttle suppression in room temperature sodium-sulfur batteries using ion selective polymer membranes. Chemical communications, 2014. 50(24): p. 3208-3210.

4. Qin, L., et al., A high-performance lithium ion oxygen battery consisting of Li2O2 cathode and lithiated aluminum anode with nafion membrane for reduced O2 crossover. Nano Energy, 2017. 40: p. 258-263.

5. Wu, Z., et al., Multi-sulfonated polyhedral oligosilsesquioxane (POSS) grafted poly (arylene ether sulfone) s for proton conductive membranes. Polymer, 2017. 123: p. 21-29.

6. Ge, L., et al., Preparation of proton selective membranes through constructing H+ transfer channels by acid-base pairs. Journal of Membrane Science, 2015. 475: p. 273-280.

7. Mauritz, K.A. and R.B. Moore, State of understanding of Nafion. Chemical reviews, 2004. 104(10): p. $4535-4586$.

8. Sigwadi, R., et al., Mechanical Strength Of Nafion $\mathbb{B} / \mathrm{ZrO} 2$ Nano-Composite Membrane. International Journal of Manufacturing, Materials, and Mechanical Engineering (IJMMME), 2018. 8(1): p. 54-65.

9. Sigwadi, R., et al., The proton conductivity and mechanical properties of Nafion ${ }^{\circledR} /$ ZrP nanocomposite membrane. Heliyon, 2019. 5(8): p. e02240.

10. Sigwadi, R., et al., WETTABILITY AND MECHANICAL STRENGTH OF MODIFIED NAFION® NANOCOMPOSITE MEMBRANE FOR FUEL CELL. Digest Journal of Nanomaterials \& Biostructures (DJNB), 2017. 12(4).

11. Sigwadi, R., Zirconia based/Nafion coposite membranes for fuel cell applications. 2013.

12. Deimede, V.A. and J.K. Kallitsis, Synthesis of poly (arylene ether) copolymers containing pendant PEO groups and evaluation of their blends as proton conductive membranes. Macromolecules, 2005. 38(23): p. 9594-9601.

13. Santiago, E., et al., Nafion-TiO 2 hybrid electrolytes for stable operation of PEM fuel cells at high temperature. Electrochimica Acta, 2009. 54(16): p. 4111-4117.

14. Vijayakumar, V. and D. Khastgir, Hybrid composite membranes of chitosan/sulfonated polyaniline/silica as polymer electrolyte membrane for fuel cells. Carbohydrate polymers, 2018. 179: p. 152-163. 
15. Albu, A.-M., et al., Novel PVA proton conducting membranes doped with polyaniline generated by in-situ polymerization. Electrochimica Acta, 2016. 211: p. 911-917.

16. Navarra, M., C. Abbati, and B. Scrosati, Properties and fuel cell performance of a Nafion-based, sulfated zirconia-added, composite membrane. Journal of power sources, 2008. 183(1): p. 109-113.

17. Chen, X.-R., Y.-H. Ju, and C.-Y. Mou, Direct synthesis of mesoporous sulfated silica-zirconia catalysts with high catalytic activity for biodiesel via esterification. The Journal of Physical Chemistry C, 2007. 111(50): p. 18731-18737.

18. Mercera, P., et al., Influence of ethanol washing of the hydrous precursor on the textural and structural properties of zirconia. Journal of materials science, 1992. 27(18): p. 4890-4898.

19. Wei, S., et al., Electrospun poly (vinyl alcohol)/ $\alpha$-zirconium phosphate nanocomposite fibers. High Performance Polymers, 2013. 25(1): p. 25-32.

20. de Oliveira, A.D. and C.A.G. Beatrice, Polymer nanocomposites with different types of nanofiller. Nanocomposites-Recent Evolutions, 2018: p. 103-104.

21. Xiao, H. and S. Liu, Zirconium phosphate ( $\mathrm{ZrP})$-based functional materials: Synthesis, properties and applications. Materials \& Design, 2018. 155: p. 19-35.

22. Allami, T., et al., Investigating Physio-Thermo-Mechanical Properties of Polyurethane and Thermoplastics Nanocomposite in Various Applications. Polymers, 2021. 13(15): p. 2467.

23. Yang C., S.S., Bocarsly A B., Tulyani S., Benziger J B., A comparison of physical properties and fuel cell performance of Nafion and zirconium phosphate/Nafion composite membranes. Journal of Membrane Science, 2004. 237(1-2): p. 145-161.

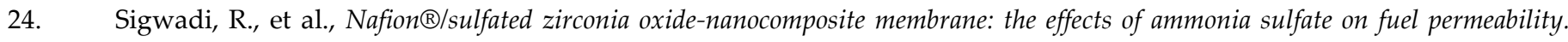
Journal of Polymer Research, 2019. 26(5): p. 1-14.

25. Vaivars, G., et al., Zirconium phosphate based inorganic direct methanol fuel cell. Mater. Sci, 2004. 10: p. $162-165$.

26. Baglio, V., A. Di Blasi, and V. Antonucci, FTIR spectroscopic investigation of inorganic fillers for composite DMFC membranes. Electrochemistry communications, 2003. 5(10): p. 862-866.

27. Yang, H., et al., Preparation of Nafion/various Pt-containing SiO 2 composite membranes sulfonated via different sources of sulfonic group and their application in self-humidifying PEMFC. Journal of membrane science, 2013. 443: p. 210-218.

28. Ostrowska, J. and A. Narebska, Infrared study of hydration and association of functional groups in a perfluorinated Nafion membrane, Part 1. Colloid and Polymer Science, 1983. 261(2): p. 93-98.

29. Zhai, Y., et al., Preparation and characterization of sulfated zirconia (SO42-/ZrO2)/Nafion composite membranes for PEMFC operation at high temperature/low humidity. Journal of membrane science, 2006. 280(1-2): p. 148-155.

30. Di Noto, V., et al., Effect of SiO2 on relaxation phenomena and mechanism of ion conductivity of [Nafion/(SiO2) $x$ ] composite membranes. The Journal of Physical Chemistry B, 2006. 110(49): p. 24972-24986.

31. Laporta, M., M. Pegoraro, and L. Zanderighi, Perfluorosulfonated membrane (Nafion): FT-IR study of the state of water with increasing humidity. Physical Chemistry Chemical Physics, 1999. 1(19): p. 4619-4628.

32. Sarkar, D., et al., Synthesis and characterization of sol-gel derived ZrO2 doped Al2O3 nanopowder. Ceramics international, 2007. 33(7): p. 1275-1282.

33. Salavati-Niasari, M., M. Dadkhah, and F. Davar, Pure cubic ZrO 2 nanoparticles by thermolysis of a new precursor. Polyhedron, 2009. 28(14): p. 3005-3009.

34. Horsley, S., D. Nowell, and D. Stewart, The infrared and Raman spectra of $\alpha$-zirconium phosphate. Spectrochimica Acta Part A: Molecular Spectroscopy, 1974. 30(2): p. 535-541.

35. Velayutham, P., A.K. Sahu, and S. Parthasarathy, A Nafion-Ceria Composite Membrane Electrolyte for Reduced Methanol Crossover in Direct Methanol Fuel Cells. Energies, 2017. 10(2): p. 259.

36. Zinadini, S., et al., Preparation of a novel antifouling mixed matrix PES membrane by embedding graphene oxide nanoplates. Journal of Membrane Science, 2014. 453: p. 292-301. 
37. Li, K., et al., Self-assembled Nafion $\AA /$ metal oxide nanoparticles hybrid proton exchange membranes. Journal of Membrane Science, 2010. 347(1-2): p. 26-31.

38. Starkweather Jr, H.W., Crystallinity in perfluorosulfonic acid ionomers and related polymers. Macromolecules, 1982. 15(2): p. 320323.

39. Kyu, T., M. Hashiyama, and A. Eisenberg, Dynamic mechanical studies of partially ionized and neutralized Nafion polymers. Canadian Journal of Chemistry, 1983. 61(4): p. 680-687.

40. Devrim, Y., et al., Improvement of PEMFC performance with Nafion/inorganic nanocomposite membrane electrode assembly prepared by ultrasonic coating technique. international journal of hydrogen energy, 2012. 37(21): p. 16748-16758.

41. Deng, Q., et al., TGA-FTi.r. investigation of the thermal degradation of Nafion ${ }^{\circledR}$ and Nafion $₫ /[$ silicon oxide]-based nanocomposites. Polymer, 1998. 39(24): p. 5961-5972.

42. Smitha, B., D.A. Devi, and S. Sridhar, Proton-conducting composite membranes of chitosan and sulfonated polysulfone for fuel cell application. international journal of hydrogen energy, 2008. 33(15): p. 4138-4146.

43. Wang, Y., et al., Influence of polymeric binders on mechanical properties and microstructure evolution of silicon composite electrodes during electrochemical cycling. Journal of Power Sources, 2019. 425: p. 170-178.

44. Lu, Z., et al., An experimental investigation of strain rate, temperature and humidity effects on the mechanical behavior of a perfluorosulfonic acid membrane. Journal of Power Sources, 2012. 214: p. 130-136.

45. Safronova, E., et al., Sensitivity of potentiometric sensors based on Nafion ${ }^{\circledR-t y p e ~ m e m b r a n e s ~ a n d ~ e f f e c t ~ o f ~ t h e ~ m e m b r a n e s ~ m e c h a n i c a l, ~}$ thermal, and hydrothermal treatments on the on their properties. Sensors and Actuators B: Chemical, 2017. 240: p. 1016-1023.

46. Xing, P., et al., Synthesis and characterization of poly (aryl ether ketone) copolymers containing (hexafluoroisopropylidene)-diphenol moiety as proton exchange membrane materials. Polymer, 2005. 46(10): p. 3257-3263.

47. Hudiono, Y., et al., Porous layered oxide/Nafion ${ }^{\circledR}$ nanocomposite membranes for direct methanol fuel cell applications. Microporous and Mesoporous Materials, 2009. 118(1-3): p. 427-434.

48. Dutta, K., S. Das, and P.P. Kundu, Effect of the presence of partially sulfonated polyaniline on the proton and methanol transport behavior of partially sulfonated PVdF membrane. Polymer Journal, 2016. 48(3): p. 301-309.

49. Yang, T., Composite membrane of sulfonated poly (ether ether ketone) and sulfated poly (vinyl alcohol) for use in direct methanol fuel cells. Journal of Membrane Science, 2009. 342(1): p. 221-226.

50. Chien, H.-C., et al., Sulfonated graphene oxide/Nafion composite membranes for high-performance direct methanol fuel cells. international journal of hydrogen energy, 2013. 38(31): p. 13792-13801.

51. Savadogo, O., Emerging membrane for electrochemical systems:(I) solid polymer electrolyte membranes for fuel cell systems. Journal of New Materials for Electrochemical Systems, 1998. 1(1): p. 47-66.

Adams, F., et al., Application of polysulfone/cyclodextrin mixed-matrix membranes in the removal of natural organic matter from water. Physics and Chemistry of the Earth, Parts A/B/C, 2014. 67: p. 71-78.

Msomi, P.F., et al., Quaternized poly (2.6 dimethyl-1.4 phenylene oxide)/Polysulfone anion exchange membrane reinforced with graphene oxide for methanol alkaline fuel cell application. Journal of Polymer Research, 2018. 25(6): p. 1-12.

54. Bose, S., et al., Polymer membranes for high temperature proton exchange membrane fuel cell: recent advances and challenges. Progress in Polymer Science, 2011. 36(6): p. 813-843.

55. Peighambardoust, S., S. Rowshanzamir, and M. Amjadi, Review of the proton exchange membranes for fuel cell applications. International journal of hydrogen energy, 2010. 35(17): p. 9349-9384.

56. D'Epifanio, A., et al., Composite nafion/sulfated zirconia membranes: effect of the filler surface properties on proton transport characteristics. Chemistry of Materials, 2009. 22(3): p. 813-821.

57. Jalani, N.H., K. Dunn, and R. Datta, Synthesis and characterization of Nafion ${ }^{\circledR}-M O 2(M=Z r$, Si, Ti) nanocomposite membranes for higher temperature PEM fuel cells. Electrochimica Acta, 2005. 51(3): p. 553-560.

58. Sacca, A., et al., ZrO2-Nafion composite membranes for polymer electrolyte fuel cells (PEFCs) at intermediate temperature. Journal of power sources, 2006. 163(1): p. 47-51. 
59. Farrokhzad, H., et al., Novel composite cation exchange films based on sulfonated PVDF for electromembrane separations. Journal of Membrane Science, 2015. 474: p. 167-174.

60. Wang, L.S., et al., Orderly sandwich-shaped graphene oxide/Nafion composite membranes for direct methanol fuel cells. Journal of Membrane Science, 2015. 492: p. 58-66.

61. Kumar, G.G. and K.S. Nahm, Polymer nanocomposites-fuel cell applications, in Advances in Nanocomposites-Synthesis, Characterization and Industrial Applications. 2011, IntechOpen.

62. Li, H.-Y. and Y.-L. Liu, Nafion-functionalized electrospun poly (vinylidene fluoride)(PVDF) nanofibers for high performance proton exchange membranes in fuel cells. Journal of Materials Chemistry A, 2014. 2(11): p. 3783-3793. 